\title{
HUBUNGAN PENDAMPING PERSALINAN DENGAN LAMA KALA II PADA IBU PRIMIGRAVIDA DI KLINIK S CURUG TANGERANG 2017
}

\author{
Yulizar $^{1}$, Zuhrotunida ${ }^{2}$ \\ Fakultas Ilmu Kesehatan Universitas Muhammadiyah Tangerang \\ Email : uniizar@gmail.com/zuhrotunida@gmail.com
}

\begin{abstract}
ABSTRAK
Ketidaksiapan menghadapi proses persalinan akan menimbulkan rasa takut dan cemas pada ibu, hal ini dapat menyebabkan partus tidak maju yang dapat membahayakan keselamatan ibu dan bayinya. Kehadiran suami, akan membawa ketenangan bagi ibu, karena proses persalinan dibutuhkan pendamping persalinan.Tujuan penelitian ini yaitu mengetahui hubungan pendamping persalinan dengan lama kala dua pada ibu bersalin primigravida diklinik s curug tangerang tahun 2017. Desain penelitian yang digunakan adalah dengan metode survei analitik dengan populasi suluruh ibu bersalin primigravida yang melahirkan dari bulan Desember hingga Februari dengan jumlah sampel 36 ibu bersalin.Variabel yang diteliti adalah pendamping persalinan dan lama kala dua. Alat ukur yang digunakan adalah lembar observasi dan partograf, cara pengambilan sampel adalah accidental sampling. Hasil penelitian menunjukan uji statistik didapat $\mathrm{P}$ value sebanyak $=0,011<\alpha(0,05)$ artinya ada hubungan yang bermakna antara pendampingan suami selama proses persalinan dengan lama kala II persalianan didapatkan nilai OR sebesar 10,313, artinya ibu bersalin primipara yang tidak didampingi suami berpeluang 10kali mengalami kala II memanjang dibandingkan dengan yang didampingi suami. Kesimpulan penelitian bidan memfasiltasi dalam memberikan konseling tentang pendamping persalinan, terutama pendampingan oleh suami selama porses persalinan,
\end{abstract}

Daftar Pustaka : 27 (2007-2015)

Kata Kunci : Pendamping persalinan, Lama Kala II

\begin{abstract}
Unpreparedness in the delivery process will cause fear and anxiety to the mother, this can lead to an unsuccessful partus that may enda The presence of the husband, will bring peace for the mother, because the process of childbirth required birth attendant. The purpose of this study is to know the relationship of companion labor with the second stage of maternal age Primigravida onclinic $S$ curug tangerang in 2017.nger the safety of both mother and baby. The research design used was analytic survey method with the population of primigravida maternity laborers who gave birth from December to February with a sample of 36 mothers. The variables studied were the labor companion and the second stage. The measuring instrument used is the observation and partographic sheet, the sampling method is accidental sampling. The result showed that $P$ value $=0,011<\alpha(0,05)$ means that there is a significant correlation between husband's assistant during labor process with time period II labor got OR value 10,313, means primipara maternal mother who was not accompanied by a husband 10kali chance to experience second stage lengthwise compared with thatConclusion of midwife's
\end{abstract}


research facilitate in giving counseling about childbirth companion, especial accompaniment by husband during labor delivery.

References : $27(2007-2015)$

Keyword : Companion of labor, old Kala II accompanied by husband.

\section{PENDAHULUAN}

Angka kematian ibu di Indonesia sampai saat ini masih sangat tinggi bila di bandingkan dengan negara-negara lain di ASEAN. Pada tahun 2007 angka kejadiannya adalah 228 kasus kematian per 100 ribu kelahiran hidup. Pada tahun 2012 angka kematian ibu meningkat menjadi 359 per 100.000 kelahiran hidup (SDKI, 2012).

Beberapa faktor penyebab langsung kematian ibu di Indonesia masih didominasi oleh perdarahan, eklampsia, partus lama, dan infeksi. Sedangkan faktor tidak langsung penyebab kematian ibu karena faktor terlambat dan terlalu. Perdarahan (42\%), Eklampsi/Preeklampsi (13\%), Abortus (11\%), Infeksi (10\%), partus lama/persalinan macet $(9 \%)$, dan penyebab lain (15\%) (SDKI, 2012). Penyebab-penyebab kematian ibu tersebut saling berkaitan satu sama lainnya.

Persalinan merupakan rangkaian proses yang berakhir dengan pengeluaran hasil konsepsi oleh ibu. Faktor-faktor yang mempengaruhi persalinan yaitu power (kekuatan yang mendorong janin keluar), passage (jalan lahir), passanger (bayi dan placenta), psikis (kondisi psikis ibu), dan penolong.

Rasa cemas pada ibu menyebabkan peningkatan tegangan otot dan gangguan aliran darah menuju otak selama proses persalinan sehingga menyebabkan kontraksi uterus terganggu, dan tenaga mendorong ibu hilang selama kala dua persalinan. Kecemasan juga dapat menyebabkan peningkatan kadar katekolamin yang dapat menurunkan aliran darah ke rahim dan plasenta, memperlambat kontraksi rahim, dan mengurangi pasokan oksigen ke janin. Hal tersebut berpotensi menyebabkan partus lama (Yuliatun, 2008).

Ketidaksiapan menghadapi proses persalinan akan menimbulkan rasa takut dan cemas pada ibu terutama pada wanita yang baru pertama kali melahirkan karena pada umumnya belum memiliki gambaran mengenai kejadian yang akan dialami pada persalinan. Hal ini dapat menyebabkan terjadi proses persalinan yang lama atau biasa disebut dengan partus macet/partus tidak maju yang dapat membahayakan keselamatan ibu dan bayinya.

Beberapa hal yang mempengaruhi respon kecemasan ibu dalam menghadapi persalinan meliputi usia, jenis kelamin, pendidikan, pengalaman pernah bersalin (paritas), lingkungan dan dukungan keluarga. Kecemasan ibu dalam menghadapi persalinan, dapat diatasi dengan menciptakan kondisi lingkungan yang aman dan nyaman serta adanya dukungan keluarga (Mochtar, 2007).

Beberapa upaya dapat dilakukan untuk meminimalkan kecemasan diantaranya dengan tindakan relaksasi napas dalam, aromaterapi, distraksi, dan dukungan sosial dari orang terdekat ibu. Suami atau orang terdekat dapat memainkan peranan penting bagi wanita yang sedang melahirkan. Suami atau orang terdekat dapat menghitung kontraksi ibu, menggosok punggungnya, mengingatkan padanya tentang teknik bernapas dan memberikan dorongan padanya untuk istirahat antar kontraksi. Dukungan selama proses persalinan dapat meminimalkan komplikasi selama persalinan. Hal ini didukung oleh penelitian Lubna dan Eileen pada tahun 2006 yang menyatakan bahwa wanita yang menerima dukungan selama persalinan, memiliki rasio yang rendah dari seksio 
sesaria, persalinan yang dibantu forcep, partus lama dan dapat mengurangi penggunaan analgesik dibandingkan dengan wanita yang tidak menerima dukungan. Dukungan dari suami untuk ibu primipara juga dapat meningkatkan kesehatan mental dan mencegah terjadinya depresi pasca partum (Leahy-Warren, McCarthy \& Corcoran, 2011).

Kehadiran suami atau kerabat dekat, akan membawa ketenangan bagi ibu, karena proses persalinan sangat dibutuhkan pendamping persalinan, untuk memberikan dukungan dan bantuan kepada ibu saat persalinan serta dapat memberikan perhatian, rasa aman, nyaman, semangat, menentramkan hati ibu, mengurangi ketegangaan ibu atau memperbaiki status emosional sehingga dapat mempersingkat proses persalinan. Dukungan suami dalam proses persalinan akan memberi efek pada ibu yaitu dalam hal emosi, emosi ibu yang tenang akan menyebabkan sel-sel sarafnya mengeluarkan hormon oksitosin yang reaksinya akan menyebabkan kontraksi pada rahim pada akhir kehamilan untuk mengeluarkan bayi. Mendampingi istri saat melahirkan juga akan membuat suami semakin menghargai istri dan mengeratkan hubungan batin di antara suami dan istri serta bayi yang baru lahir (Indrayani, 2013).

Berdasarkan penelitian yang dilakukan oleh Desi (2014), menemukan adanya perbedaan lama persalinan kala II antara responden yang didampingi suami dengan responden yang tidak didampingi suami. Lama persalinan kala II responden yang didampingi suami tampak lebih cepat dibandingkan dengan lama persalinan kala II responden yang tidak didampingi suami. Hal ini menunjukkan ada pengaruh pendampingan suami terhadap lamanya persalinan kala II Di Ruang Delima RSUD dr.H.Abdul Moeloek Provinsi Lampung Tahun 2014. Penelitian lain yang dilakukan oleh Jusri A (2015) juga menunjukkan adanya hubungan yang bermakna antara pendampingan suami dengan Intensitas Nyeri Persalinan Kala I Fase Aktif Deselarasi.
Berdasarkan studi pendahuluan yang dilakukan di Klinik S, Curug, Kabupaten Tangerang pada bulan September tahun 2016 didapatkan data sebanyak 29 ibu bersalin secara normal. Sebanyak $19 \mathrm{ibu}$ $(65,52 \%)$ yang didampingi suami selama proses persalinan merasa nyaman dan tenang, sementara $10 \mathrm{ibu}(34,48 \%)$ yang tidak didampingi suami merasa kurang tenang karena mereka sangat membutuhkan dukungan suami sepenuhnya pada saat proses persalinan.

Berdasarkan latar belakang tersebut, penulis merasa tertarik untuk melakukan penelitian tentang "Hubungan pendamping persalinan dengan lama kala II pada ibu primigravida di Klinik S, Curug, Kabupaten Tangerang tahun 2017”.

\section{METODE PENELITIAN}

Metode yang digunakan dalam penelitian ini adalah metode survey analitik. Dengan pendekatan observasi secara langsung, pengambilan data dengan cara accidental sampling dengan pendekatan secara langsung melalui lembar obsevasi dan partograf, yang dilaksanakan pada bulan Desember 2016- Januari 2017 di klinik spesialis syafyeni Tangerang dengan jumlah populasi 86 responden dan sampel 36 responden.

\section{HASIL DAN PEMBAHASAN}

\section{Analisa Data Univariat}

\section{a. Distribusi Frekuensi Pendampingan Suami}

Distribusi pendampingan suami selama proses kala II didapatkan hasil perhitungan pada table 1 berikut: 


\section{Tabel 1}

Distribusi frekuensi ibu bersalin berdasarkan pendamping persalinan di klinik S, kec. Curug Periode Desember tahun 2016 -

Februari tahun 2017

\begin{tabular}{cccc} 
No & $\begin{array}{c}\text { Pendamping } \\
\text { Persalinan }\end{array}$ & Frekuensi & $\begin{array}{c}\text { Presentase } \\
(\mathbf{\%})\end{array}$ \\
\hline 1. & $\begin{array}{c}\text { Didampingi } \\
\text { suami }\end{array}$ & 23 & $63,9 \%$ \\
2. & $\begin{array}{c}\text { Tidak } \\
\text { didampingi } \\
\text { suami }\end{array}$ & 13 & $36,1 \%$ \\
& Jumlah & $\mathbf{3 6}$ & $\mathbf{1 0 0} \%$ \\
\hline
\end{tabular}

Hasil distribusi frekuensi data responden tentang Pendampingan suami selama proses kala II, diketahui bahwa sebanyak 23 ibu bersalin $(63,9 \%)$ didampingi suami selama proses persalinan kala II dan sebanyak 13 ibu bersalin $(36,1 \%)$ didampingi suami selama proses persalinan kala I

\section{b. Distribusi Frekuensi Lama Kala II}

Distribusi kejadian Lama kala II didapatkan hasil perhitungan pada tabel 2 berikut:

\section{Tabel 2}

Distribusi frekuensi ibu bersalin berdasarkan lama kala II di klinik S, kec. curug periode Desember tahun 2016 -Februari tahun 2017

\begin{tabular}{cccc}
\hline No & $\begin{array}{c}\text { Lama } \\
\text { Kala II }\end{array}$ & Frekuensi & $\begin{array}{c}\text { Presentase } \\
(\boldsymbol{\%})\end{array}$ \\
\hline 1. & Normal & 17 & $42,7 \%$ \\
\hline 2. & $\begin{array}{c}\text { Tidak } \\
\text { Normal }\end{array}$ & 19 & $52,8 \%$ \\
\hline \multicolumn{2}{c}{ Jumlah } & $\mathbf{3 6}$ & $\mathbf{1 0 0 \%}$ \\
\hline
\end{tabular}

Hasil distribusi frekuensi data responden tentang lama kala II, diketahui bahwa sebanyak 19 responden $(42,7 \%)$ mengalami kala II secara tidak normal dan sebanyak 17 responden $(42,7 \%)$ mengalami kala II secara normal.

\section{Analisa Data Bivariat}

\section{Hubungan Pendamping Persalinan Dengan Lama Kala II}

Hubungan pendamping persalinan dengan lama kala II didapatkan hasil perhitungan pada table 3 sebagai berikut :

Tabel 3

Tabel Hubungan pendamping persalinan dengan lama kala II di klinik S, kec.curug periode Desember tahun 2016 - Februari tahun 2017

\begin{tabular}{|c|c|c|c|c|c|c|c|c|c|}
\hline \multirow{2}{*}{ No } & \multirow{2}{*}{$\begin{array}{c}\text { Pendamping } \\
\text { Persalinan }\end{array}$} & \multicolumn{4}{|c|}{ Lama Kala II } & Jumlah & \% & $\begin{array}{c}\text { P } \\
\text { Value }\end{array}$ & OR \\
\cline { 2 - 7 } & Normal & $\mathbf{\%}$ & $\begin{array}{c}\text { Tidak } \\
\text { Normal }\end{array}$ & $\%$ & & & \\
\hline 1. & $\begin{array}{c}\text { Didampingi } \\
\text { suami }\end{array}$ & 15 & 65,2 & 8 & 34,8 & 23 & 100 & & 10,313 \\
2. & $\begin{array}{c}\text { Tidak } \\
\text { didampingi } \\
\text { suami }\end{array}$ & 2 & 15,4 & 11 & 84,6 & 13 & 100 & 0,011 & $\begin{array}{c}(1,821 \\
- \\
58,394)\end{array}$ \\
\hline
\end{tabular}

Dari tabel diatas diketahui bahwa ibu bersalin yang selama proses persalinan kala II nya tidak didampingi suami mengalami kala II tidak normal lebih banyak yaitu 11 orang $(84,6 \%)$, dan ibu bersalin yang selama proses kala II nya tidak didampingi suami mengalami kala II normal hanya 2 orang $(15,4 \%)$

Hasil uji statistik diperoleh nilai $P$ value $=0,011<\alpha(0,05)$. Hal ini 
menunjukkan bahwa Ha diterima artinya ada hubungan antara pendampingan suami selama proses persalinan dengan lamanya kala II persalinan.

Nilai OR sebesar 10,313 artinya bahwa ibu bersalin primipara yang proses persalinan nya tidak didampingi suami akan mengalami lama kala II tidak normal sebesar 10 kali dibandingkan dengan ibu bersalin primipara yang proses persalinan nya didampingi suami.

\section{PEMBAHASAN}

Setelah dilakukan uji statistik univariat dan bivariat diperoleh data sebagai berikut:

\section{Distribusi pendamping persalinan}

Hasil distribusi frekuensi data responden tentang Pendampingan suami selama proses kala II, diketahui bahwa sebanyak 23 ibu bersalin $(63,9 \%)$ didampingi suami selama proses persalinan kala II dan sebanyak 13 ibu bersalin $(36,1 \%)$ didampingi suami selama proses persalinan kala II.

\section{Distribusi lama kala II}

Hasil distribusi frekuensi data responden tentang lama kala II, diketahui bahwa sebanyak 19 responden $(42,7 \%)$ mengalami kala II secara tidak normal dan sebanyak 17 responden $(42,7 \%)$ mengalami kala II secara normal.

Etiologi terjadinya kala II lama ini adalah multikomplek dan tentu saja bergantung pada pengawasan selagi hamil, pertolongan persalinan yang baik dan penatalaksanaannya. Faktor-faktor yang berperan dalam persalinan yaitu Tenaga atau kekuatan (Power), Jalan lahir (Passage), Janin (Passanger), Psikis ibu dan Penolong.

\section{Hubungan pendamping persalinan dengan lama kala II}

Hasil penelitian menunjukkan bahwa ibu bersalin yang selama proses persalinan kala II nya tidak didampingi suami mengalami kala II tidak normal lebih banyak yaitu 11 orang $(84,6 \%)$, dan ibu bersalin yang selama proses kala II nya tidak didampingi suami mengalami kala II normal hanya 2 orang $(15,4 \%)$

Hasil uji statistik diperoleh nilai $\mathrm{P}$ value $=0,011<\alpha(0,05)$. Hal ini menunjukkan bahwa Ha diterima artinya ada hubungan antara pendampingan suami selama proses persalinan dengan lamanya kala II persalinan.

Hal tersebut sesuai dengan teori yang menyebutkan bahwa etiologi terjadinya kala II lama adalah multikomplek, diantaranya adalah wanita yang cemas dan ketakutan. (Prawirohardjo, 2014).

Dengan demikian, manfaat menghadirkan pendamping persalinan terutama suami, tidak hanya akan dirasakan oleh ibu, suami pun akan merasakan manfaat nya. Manfaat yang didapatkan oleh suami ketika mendampingi istri melahirkan adalah akan timbul rasa kasih sayang yang lebih besar, karena ia akan mengetahui bagaimana perjuangan seorang istri dalam melahirkan anaknya.

Setelah didapatkan nilai OR sebesar 10,313, artinya ibu bersalin primipara yang tidak didampingi suami beresiko $10 \mathrm{kali}$ lipat mengalami kala II memanjang dibandingkan yang didampingi suami.

Hal tersebut juga sesuai dengan hasil penelitian yang dilakukan oleh Desi , 2014 yang menemukan adanya perbedaan lama persalinan kala II antara responden yang didampingi suami dengan responden yang tidak didampingi suami. Lama persalinan kala II responden yang didampingi suami tampak lebih cepat dibandingkan dengan lama persalinan kala II responden yang tidak didampingi suami. Hal ini menunjukkan ada pengaruh pendampingan suami terhadap lamanya persalinan kala II Di Ruang Delima RSUD dr.H.Abdul Moeloek Provinsi Lampung Tahun 2014.

Dengan demikian, penulis menyimpulkan bahwa hadirnya 
pendamping persalinan, terutama suami dapat mengurangi risiko terjadinya kala II lama atau memanjang. Berdasarkan penelitian yang dilakukan oleh Hastuti, 2009 diperoleh hasil dimana pada kala II terdapat perbedaan yang bermakna antara lama persalinan ibu yang ditunggu suami dengan yang oleh selain suami (P= $0,004 ;<0,05)$. Artinya dukungan suami memiliki konstribusi yang positif bagi ibu sehingga memberikan ketenangan psikologis bagi ibu sehingga persalinan dapat berjalan lancar. Respon psikologis ibu dapat mempengaruhi kemajuan persalinan dan kemungkinan melemahnya kekuatan kontraksi. Dengan demikian, suami merupakan pemberi dukungan yang paling tepat selama persalinan karena kemampuannya mengendalikan diri sendiri maupun istrinya dalam mengikuti arahan petugas medis sebagai pemimpin persalinan.

Kenyamanan ibu saat proses persalinan merupakan factor psikologis yang harus dipenuhi oleh tenaga kesehatan, jika ibu merasa tenang dan nyaman, maka persalinan akan berlangsung secara normal.

\section{KESIMPULAN}

1. Adanya hubungan antara pendamping persalinan dengan lama kala II pada ibu bersalin di Klinik S, Curug, Kabupaten Tangerang tahun 2017.

2. Dari 23 responden yang dilakukan pendampingan oleh suami ditemukan bahwa $65,2 \%$ ibu melewati proses kala II yang normal sedangkan ibu yang tidak dilakukan pendampingan oleh suami sebesar $84,6 \%$ mengalami kala II lama.

3. Hasil uji statistik diperoleh nilai $P$ value $=0,011<\alpha(0,05)$. Artinya ada hubungan antara pendampingan suami selama proses persalinan dengan lamanya kala II persalinan.

4. Ibu bersalin primipara yang tidak didampingi suami berpeluang $10 \mathrm{kali}$ mengalami persalinan kala II memanjang dibandingkan yang didampingi oleh suami.

\section{SARAN}

1. Sebaiknya bidan dapat memberikan konseling mengenai segala sesuatu yang berhubungan dengan proses persalinan, salah satunya adalah peran pendamping terutama suami dalam proses persalinan. Dengan pemberian konseling yang baik dan benar, ibu hamil akan mengetahui apa saja manfaat pendamping peralinan yang dapat membantu kelancaran proses persalinan, konseling tersebut terutama dibutuhkan oleh seorang ibu hamil yang sedang hamil trimester III.

2. Bagi fakultas kesehatan Universitas Muhammadiyah Tangerang terutama prodi DIV Kebidanan terus mengasah kemampuan mahasiswanya dalam melakukan penelitian dan analisis masalah.

3. Sebaiknya sebelum menghadapi proses persalinan, ibu lebih kritis dalama menanyakan segala sesuatu yang berhubungan dengan proses persalinan, salah satunya adalah pendamping persalinan dan factor resiko kala II memanjang . Dengan penambahan wawasan mengenai pendamping persalinan dan lama kala II, ibu jadi lebih mengetahui segala sesuatu tentang proses prsalinannya.

4. Bagi penelitian selanjutnya disarankan untuk menambahkan variabel his dan kekuatan ibu saat meneran agar penelitian ini lebih sempurna

5. Bagi tenaga kesehatan lebih menekankan kembali konseling tentang pentingnya kediran suami pada saat ibu yang akan bersalin sehingga proses persalinan berjalan lancar dan angka morbiditas dan mortalitas dapat di tekan. 


\section{DAFTAR PUSTAKA}

APN, 2015. Asuhan Persalinan Normal. Jakarta : JNPK-KR

Azwar, Saifuddin. (2014). Metode Penelitian. Yogyakarta: Pustaka Pelajar

Budiarto, E, 2012. Biostatika untuk kedokteran dan Kesehatan Masyarakat. Jakarta : EGC.

Cendika, D, dan Indarwati. (2010). Panduan Pintar dan Hamil Melahirkan. Jakarta : Wahyu Media.

Dahlan, M. Sopiyudin, 2013. Statitiska Untuk Kedokteran dan Kesehatan. Jakarta: Salemba Medika.

Desi Eka Wijaya, Rillyani \& Andini. 2014. Dalam jurnal "Pengaruh Pendampingan Suami terhadap Lamanya Kala Persalinan Kala II di Ruang Delima RSUD DR.H. Abdul Moeloek Lampung"

Djami, Moudy \& Indrayani. 2013. Asuhan Persalinan dan Bayi Baru Lahir. Jakarta : CV Trans Info Media.

Eniyati, dan Putri Melisa R 2012, Asuhan Kebidanan Pada Ibu Bersalin. Pustaka Belajar : Yogyakarta

Friedman, Marilyn M. (2010). Buku ajar keperawatan keluarga : Riset, Teori dan

Hastuti, Budi S.F. 2009. Dalam jurnal "Pengaruh Dukungan Suami Terhadap Lama Persalinan Kala II Pada Ibu Primipara,Yogyakarta"

Indriyani, Diyan \& Asmuji. 2014. Buku Ajar Keperawatan Maternitas. Yogyakarta: Ar-Ruzz Media.

Jusri Adam. 2015. Dalam jurnal "Hubungan antara Umur, Parietas dan Pendampingan Suami dengan Intensitas Nyeri Persalinan Kala I Fase Aktif Deselarasi di Ruang Bersalin
RSUD Prof. Dr. H. Aloei Saboe Kota Gorontalo"

Leahy-Warren, P. \& McCarthy, G. 2011 Maternal parental self-efficacy in the postpartum period. Midwifery

Lockhart A dan Saputra L. 2014. Asuhan Kebidanan Kehamilan Fisiologis \& Patologis. Tangerang Selatan: Binarupa Aksara.

Manuaba. 2012. Ilmu Kebidanan, Penyakit Kandungan dan KB untuk Pendidikan Bidan Edisi 2. Jakarta: EGC.

Mochtar 2007. Buku Saku Keperawatan Jiwa Edisi 4. Jakarta : EGC.

Mochtar, Rustam, 2011. Sinopsis Obstetri Fisiologi Patologi, Jilid 2. EGC. Jakarta

Niven, Neil. 2008. Psikologi Kesehatan : Pengantar Untuk Perawat Dan Profesional. Jakarta: EGC

Notoatmodjo, Soekidjo. 2012. Promosi kesehatan dan Perilaku Kesehatan. Jakarta : EGC

Pevi Primasnia, Wagiyo. 2013. Dalam jurnal "hubungan pendampingan suami dengan tingkat kecemasan ibu primigravida dalam menghadapi proses persalinan kala $\mathrm{i}$ di rumah bersalin kota ungaran"

Prawirohardjo, Sarwono. 2010. Buku Acuan Nasional Pelayanan Kesehatan Maternal dan Neonatal. Jakarta : PT Bina Pustaka Sarwono Prawirohardjo.

Rohani.dkk.2011. Asuhan Pada Masa Persalinan. Jakarta : Salemba Medika.

Survey Demografi dan Kesehatan Indonesia (SDKI) tahun 2012

Suyati, Ninik Azizah. 2011. Dalam jurnal "Hubungan Pengetahuan Ibu Hamil tentang Proses Persalinan dengan Tingkat Kecemasan Menghadapi Persalinan di desa Sambirejo Jogoroto" 
Varney,H., 2007. Buku Ajar Asuhan Kebidanan Edisi 4. Jakarta: EGC

Winkjosastro, Hanifa, 2011. Ilmu kebidanan. Edisi tiga, YBP. SP : Jakarta

Yuliatun, L. 2008. Penangangan Nyeri Persalinan Dengan Metode Nonfarmakologi. Malang: Bayumedia Publishing.

https://dokterindonesiaonline.com/tag/inil ah-penyebab-angka-kematian-ibumeningkat-di-indonesial 